\title{
Trace Element Distributions in Biodegraded Crude Oils and Fractions from the Potiguar Basin, Brazil
}

\author{
Christiane Duyck, ${ }^{a}$ Norbert Miekeley, ${ }^{* a}$ Teresa C. O. Fonseca, ${ }^{b}$ Peter Szatmari ${ }^{b}$ and \\ Eugênio Vaz dos Santos Neto ${ }^{b}$
} ${ }^{a}$ Departamento de Química, Pontifícia Universidade Católica, Rua Marquês de São Vicente 225,
22451-900 Rio de Janeiro-RJ, Brazil

${ }^{b}$ Petrobras Research and Development Center, Av. Jequitibá, 950, Cidade Universitária, 21941-598 Rio de Janeiro-RJ, Brazil

\begin{abstract}
Perfis de distribuição de elementos traços foram determinados em óleos crus de reservatórios biodegradados situados ao longo de um caminho de migração secundaria (Bacia de Potiguar, Brasil). As amostras foram fracionadas em asfaltenos, parafinas, aromáticos e polares e resina para determinação de 22 elementos traços por ICP-MS. Esses se concentram nas frações de resina e asfaltenos, exceto $\mathrm{V}$ e Ni também encontrados na fração de aromáticos e polares. V, Co, Ni e Mo foram influenciados por processos de biodegradação e acumulam-se nas amostras mais afetadas e de maior distância de migração. Variações semelhantes da razão Ni/V nos aromáticos e polares e dos índices de homohopano e gamacerano nas parafinas evidenciaram também a influencia da biodegradação. As distribuições elementares foram similares para os óleos e seus asfaltenos, sugerindo que esses últimos, mais refratários que o óleo original, possam ser usados como uma ferramenta geoquímica inorgânica robusta de impressão digital para caracterização de óleos.
\end{abstract}

Trace element distribution patterns were determined in crude oils from onshore biodegraded reservoirs along a secondary migration trend (Potiguar Basin, Brazil). Samples were fractionated into asphaltenes, paraffins, aromatics and polars and resins for the determination of 22 trace elements by ICP-MS. Most of them are strongly enriched in the resin and asphaltene fractions, but $\mathrm{V}$ and $\mathrm{Ni}$ are also associated with the aromatic and polar fractions. $\mathrm{V}, \mathrm{Co}, \mathrm{Ni}$ and Mo were influenced by biodegrading processes and accumulate in the most affected and migrated samples. Variations of the $\mathrm{Ni} / \mathrm{V}$ ratio in aromatics and polars, matching those of homohopane and gammacerane indexes in paraffin, evidenced also the influence of biodegradation. Very similar elemental distribution patterns in oil and corresponding asphaltenes were observed, suggesting that the latter fraction, more refractory than the original oil, can be used as a robust inorganic geochemical fingerprint for oil characterization.

Keywords: secondary oil migration, biodegradation, asphaltenes, trace elements, ICP-MS

\section{Introduction}

During more than 70 years since the discovery of metalloporphyrins in petroleum, the origin and significance of trace elements in petroleum has been poorly investigated. ${ }^{1}$ Most information is available on $\mathrm{Ni}$ and $\mathrm{V}$, which are present in almost all crude oils derived from type II and III kerogen and can be bounded to porphyrins. ${ }^{2,3}$ The reason for this lack of information on other trace elements, generally present in much lower concentrations, is mostly due to limitations of analytical methods for such complex matrices like crude oil and its heavy

*e-mail: miekeley@puc-rio.br fractions. Up to date, several elements (e.g. $\mathrm{V}, \mathrm{Fe}, \mathrm{Co}, \mathrm{Ni}, \mathrm{Cu}$ ) from the first-row transition series, which are preferentially used in geochemical studies of elemental distribution and source effects, have been determined in crude oils by techniques such as atomic absorption spectrometry, X-ray fluorescence spectrometry, ICP OES, and more recently, by ICP-MS. ${ }^{4-10}$

Trace elements in crude oil are distributed between chromatographic fractions, such as aromatics, resins and the high molecular weight compounds of asphaltenes. ${ }^{11}$ Asphaltenes are dissolved in the bulk oil by micelle formation with the resin and are insoluble in $\mathrm{n}$-alkanes. ${ }^{12}$ Together, asphaltenes and resins account to up to $100 \%$ of the trace element content of crude oil. 
The present paper investigates trace element distributions in asphaltenes, aromatics and resin separated from crude oil samples, and possible relationships between elemental occurrences and secondary effects, such as biodegradation and water contact, observed in oils generated by one source rock in a unique case of long-distance migration in the onshore Potiguar Basin, Brazil. ${ }^{13-16}$ The unique source of the studied oils excludes overprinting effects of source mixing that would difficult geochemical interpretation. This work is part of a more extensive study including the generation of a database on the inorganic composition of Brazilian crude oils. ${ }^{17,18}$

\section{Materials and Methods}

\section{Samples and origin}

Ten crude oil samples, A, B, C1, C2, C3, D, E1, E2, E3 and $\mathrm{F}$, were collected in the onshore Potiguar Basin (RN), Northeast Brazil. The letter designs the field, the number the reservoir, like $\mathrm{C} 1$ and $\mathrm{C} 2$ are from the same field but different reservoirs, classified according to the direction of the migration pathway $(\mathrm{A} \rightarrow \mathrm{F})$. This oil-prolific basin has an onshore area of about $21,500 \mathrm{~km}^{2}$, and the studied oil accumulations are lined up along more than $120 \mathrm{~km}$ inside the continent. The samples were chosen according to their representativity along the migration pathway and coincided with an imaginary line between the offshore effective source pods and the trend (Figure 1a). In a first approach, ten samples were considered sufficient since no source mixing was observed..$^{13}$ The reservoirs depths are between $500 \mathrm{~m}$ and $300 \mathrm{~m}$ for the first $70 \mathrm{~km}$ from coastline, and about $250 \mathrm{~m}$ in the more distant part of the trend. The offshore source rocks were deposited during the Aptian, under the transitional stage (lacustrine - marine) of the Brazilian margin and are composed mostly by marls and shales (Alagamar Formation). The carrier beds, known as Açu Formation, are composed by sandstones with intervals having good porosity and permeability. The migration path is structurally controlled by two major fault systems (NE-SW and NW-SE), which were responsible for the oil distribution and trapping in this part of the Basin. ${ }^{19}$

\section{Oil fractionation procedure}

Details of the procedure were described in earlier work, and therefore only the general aspects will be summarized here. ${ }^{9,18}$ The crude oil samples were deasphaltened by boiling one hour in n-heptane and the heptane-soluble portion (maltenes) separated by elution chromatography (activated Silicagel column, $1=50 \mathrm{~cm}$. i.d. $=2.2 \mathrm{~cm}$ ) into a)

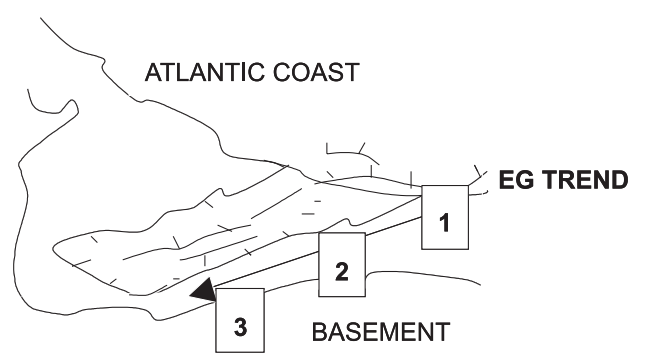

b)
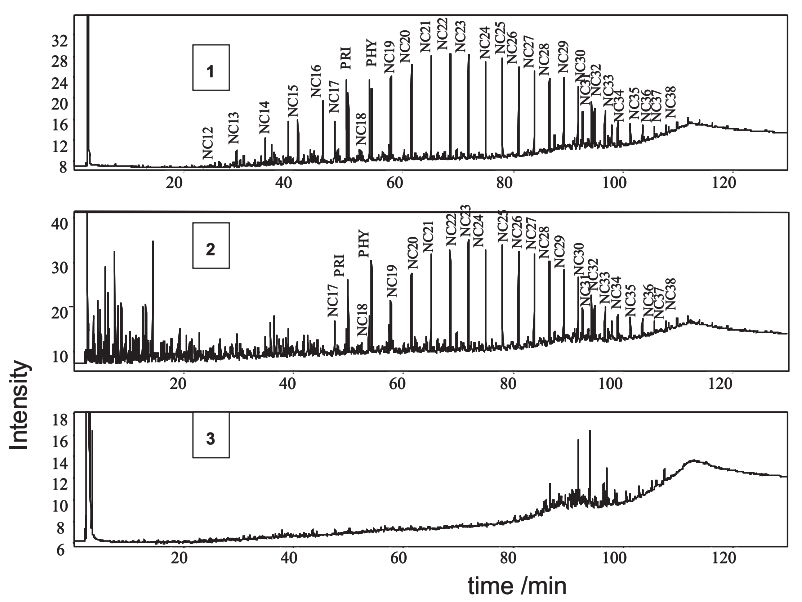

Figura 1. a) Secondary migration along the E.G. trend in the Potiguar Basin (Brazil), adapted from Trindade et al., ${ }^{13}$ 1992. b) Whole oil analysis (GC-FID) of crude oils and their relative sample location in the trend: 1) sample A; 2) sample $\mathrm{C}-1$ and 3) sample $\mathrm{F}$.

three fractions: (1) paraffins and light aromatics (elution with $\mathrm{n}-\mathrm{C}_{7} \mathrm{H}_{16}$ then $\mathrm{n}-\mathrm{C}_{7} \mathrm{H}_{16} / \mathrm{CH}_{2} \mathrm{Cl}_{2}, 50 \% \mathrm{v} / \mathrm{v}$ ), (2) aromatics and labile polars $\left(\mathrm{n}-\mathrm{C}_{7} \mathrm{H}_{16} / \mathrm{CH}_{2} \mathrm{Cl}_{2}, 50 \% \mathrm{v} / \mathrm{v}\right.$ then 200 $\left.\mathrm{CH}_{2} \mathrm{Cl}_{2}\right)$ and (3) resin $\left(\mathrm{CH}_{3} \mathrm{Cl} / \mathrm{CH}_{3} \mathrm{OH} / \mathrm{H}_{2} \mathrm{O}, 65: 25: 4, \mathrm{v} / \mathrm{v} / \mathrm{v}\right)$. The heptane-insoluble asphaltene fraction was recovered by dissolution in toluene.

\section{Trace element determination by ICP-MS}

Concentrations of $\mathrm{V}, \mathrm{Ni}, \mathrm{Co}, \mathrm{Cu}, \mathrm{Zn}, \mathrm{Mo}$ and $\mathrm{Pb}$ were determined in the original oil, as well as in the asphaltene and other fractions, after sample dissolution in toluene, by ICP-MS. The equipment used was an ELAN 5000 ICP-MS (PerkinElmer-Sciex, Concord, ON, Canada) in combination with an ultrasonic nebulizer (U-6000AT, Cetac Technologies Inc., Omaha, NB, USA) to reduce the carbon content introduced into the plasma and to enhance detection sensitivity. The argon plasma was operated at $1,500 \mathrm{~W}$ and an argon/oxygen mixture $\left(0.6 / 0.2 \mathrm{~L} \mathrm{~min}^{-1}\right)$, introduced into the sample injector (alumina, i.d. $=0.8$ $\mathrm{mm}$ ), was used additionally to avoid carbon build-up at the spectrometer interface. Other operational parameters (Table 1) were similar as reported previously. ${ }^{9,18}$ Limits 
Table 1. Operational conditions and performance data of the USN-ICP-MS technique for the analysis of crude oil and fractions in toluene and aqueous solutions

\begin{tabular}{|c|c|c|}
\hline USN & Toluene solution (A) & Aqueous solution (B) \\
\hline Heater & $20-25^{\circ} \mathrm{C}$ & $120^{\circ} \mathrm{C}$ \\
\hline Chiller & $-14^{\circ} \mathrm{C}$ & $4^{\circ} \mathrm{C}$ \\
\hline Solution uptake rate $\left(\mathrm{mL} \mathrm{min}^{-1}\right)$ & 1.2 & 1.8 \\
\hline \multicolumn{3}{|l|}{ ICP-MS } \\
\hline Plasma forward power (W) & 1500 & 1100 \\
\hline Ar plasma $\left(\mathrm{L} \min ^{-1}\right)$ & 15.0 & 15.0 \\
\hline Ar auxiliary $\left(\mathrm{L} \min ^{-1}\right)$ & 1.00 & 1.00 \\
\hline Ar nebulizer $\left(\mathrm{L} \min ^{-1}\right)$ & 0.600 & 1.120 \\
\hline $\mathrm{O}_{2}$ nebulizer $\left(\mathrm{L} \mathrm{min}^{-1}\right)$ & 0.200 & None \\
\hline Injector diameter (mm) & 0.8 & 1.5 \\
\hline Data acquisition & \multicolumn{2}{|c|}{$\begin{array}{l}\text { Resolution: normal; Scanning mode: peak hop; Dwell time }=100 \mathrm{~ms} \text {; Time } / \text { Replicate }=100 \mathrm{~ms} \text {; } \\
\text { Number of replicates }=4 \text {; Readings per replicate }=1\end{array}$} \\
\hline $\begin{array}{l}\text { Isotopes measured }(\mathrm{m} / \mathrm{z}) \text { and their LOD in brack- } \\
\text { ets }\left(3 \sigma / \text { slope: in } \mu \mathrm{g} \mathrm{L}^{-1} \text { for } \mathrm{A} \text { and } \mathrm{ng} \mathrm{L} \mathrm{L}^{-1} \text { for } \mathrm{B}\right) \text {. }\end{array}$ & $\begin{array}{c}{ }^{51} \mathrm{~V}(0.02),{ }^{59} \mathrm{Co}(0.1),{ }^{60} \mathrm{Ni}(0.1),{ }^{65} \mathrm{Cu}(0.1) \\
{ }^{66} \mathrm{Zn}(0.35),{ }^{95} \mathrm{Mo}(0.04),{ }^{208} \mathrm{~Pb}(0.2)\end{array}$ & $\begin{array}{c}{ }^{23} \mathrm{Na}(0.54) *,{ }^{26} \mathrm{Mg}(0.95) *,{ }^{44} \mathrm{Ca}(2.45) *,{ }^{53} \mathrm{Cr}(60), \\
{ }^{55} \mathrm{Mn}(40),{ }^{57} \mathrm{Fe}(4.1) *,{ }^{69} \mathrm{Ga}(7),{ }^{75} \mathrm{As}(33),{ }^{77} \mathrm{Se}(50), \\
{ }^{89} \mathrm{Y}(1),{ }^{139} \mathrm{La}(3),{ }^{140} \mathrm{Ce}(2),{ }^{141} \mathrm{Pr}(2),{ }^{16} \mathrm{Nd}(8), \\
{ }^{152} \mathrm{Sm}(0.4),{ }^{153} \mathrm{Eu}(1),{ }^{157} \mathrm{Gd}(3),{ }^{159} \mathrm{~Tb}(0.7),{ }^{163} \mathrm{Dy}(2), \\
{ }^{165} \mathrm{Ho}(1),{ }^{166} \mathrm{Er}(2),{ }^{169} \mathrm{Tm}(0.6),{ }^{172} \mathrm{Yb}(2),{ }^{175} \mathrm{Lu}(0.5)\end{array}$ \\
\hline
\end{tabular}

*LOD in $\mu \mathrm{g} \mathrm{L}{ }^{-1}$, the Meinhard nebulizer-cyclonic spray chamber system was used instead of the USN because of higher elemental concentrations.

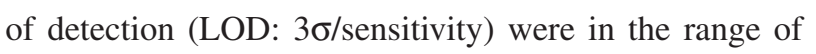
$0.02 \mu \mathrm{g} \mathrm{L}^{-1}(\mathrm{~V})$ to $0.35 \mu \mathrm{g} \mathrm{L}-1$ (Zn). Method detection limits (MDL in $\mathrm{ng} \mathrm{g}^{-1}$ ) were higher according to the dilution factor used (typically, 100 times).

Other elements, including $\mathrm{Y}$ and the light rare earth elements, were determined after sample decomposition in a microwave system. Triplicates of the oil samples $(0.150$ $\mathrm{g})$ and duplicates of their asphaltenes $(0.050 \mathrm{~g})$ were decomposed by $\mathrm{HNO}_{3} / \mathrm{H}_{2} \mathrm{O}_{2}$ in a microwave oven (Mars 5, CEM Corp., Matthews, NC, USA) using a procedure adapted from Fonseca. ${ }^{17}$ The resulting solutions were analyzed under standard conditions by ICP-MS using, when necessary, ultrasonic nebulization for signal enhancement (Table 1). LODs were similar to those obtained in previous work and ranged from $0.0004 \mu \mathrm{g} \mathrm{L}^{-1}(\mathrm{Sm})$ to $2.45 \mu \mathrm{g} \mathrm{L}{ }^{-1}(\mathrm{Ca}) .^{20}$

Accuracy and repeatability of both methods was determined by the analysis of one of the few available standard reference materials (SRM NIST 1634c, residual fuel oil). Within the uncertainty of the certified elements $\mathrm{Co}, \mathrm{Ni}$ and $\mathrm{V}$, concordant results were obtained for these elements and both sample preparation/introduction methods (Table 2). Data quality of the results for other elements, for which no oil-CRM is available, was assessed by recovery tests with $50 \mu \mathrm{g} \mathrm{L}^{-1}$ or $5 \mu \mathrm{g} \mathrm{L}^{-1}$ spiked solutions (Certipur Multielement Standard IV, Merck, Darmstadt, Germany; PE-12 and PE-17, PerkinElmer-Sciex, Concord, ON, Canada). Good to acceptable recoveries were measured, with values between $94 \%$ (Pr) and $121 \%$ (Ca). Complementary data on method performance were obtained by the determination of a $900 \mathrm{mg} \mathrm{kg}^{-1}$ Conostan
S21 standard (Conoco Inc., Houston TX, USA), resulting in percentage errors between $-9 \%(\mathrm{Mg})$ to $-4 \%(\mathrm{Ca}){ }^{9}{ }^{918}$ Confidence on the analytical results is also confirmed by the good to acceptable final mass balances for $\mathrm{V}, \mathrm{Co}, \mathrm{Ni}$, $\mathrm{Cu}, \mathrm{Zn}, \mathrm{Mo}$ and $\mathrm{Pb}$, in which the elemental concentrations of all different fractions are integrated (Table 2 and 3 ).

Table 2. Results on the determination of certified elements ( $\mathrm{V}, \mathrm{Ni}$ and $\mathrm{Co}$ ) in SRM NIST $1634 \mathrm{c}$ and its separated fractions of aromatics and polars $(\mathrm{a}+\mathrm{p})$, resin and asphaltenes (asph) with their respective mass balance $(m b, \%)$ by ICP-MS with two different sample preparation/introduction techniques: dissolution in toluene and wet digestion in a microwave system. (Mean concentrations in $\mathrm{mg} \mathrm{kg}^{-1} \pm \mathrm{SD} ; n=3$ )

\begin{tabular}{lccc}
\hline Element / fraction & $\begin{array}{c}\text { Dissolution in } \\
\text { toluene }\end{array}$ & Wet digestion & $\begin{array}{c}\text { NIST certified } \\
\text { values }\end{array}$ \\
\hline $\mathrm{V}$ & $25.8 \pm 0.6$ & $27.8 \pm 0.4$ & $28.2 \pm 0.4$ \\
$\mathrm{Ni}$ & $15.5 \pm 0.5$ & $17.3 \pm 0.5$ & $17.5 \pm 0.2$ \\
$\mathrm{Co}$ & $0.16 \pm 0.01$ & $0.142 \pm 0.006$ & $0.151 \pm 0.005$ \\
$\mathbf{V}(\mathbf{a}+\mathbf{p})$ & $4.77 \pm 0.09$ & $5.6 \pm 0.7$ & $n . r$. \\
$\mathrm{resin}$ & $66.0 \pm 0.7$ & $52.5 \pm 1$ & $n . r$. \\
$\mathrm{asph}$ & $141 \pm 5$ & $169 \pm 11$ & $n . r$. \\
$\mathrm{mb}$ & 112 & 108 & \\
$\mathrm{Ni}(\mathrm{a}+\mathrm{p})$ & $11.5 \pm 0.3$ & $13.4 \pm 0.5$ & $n . r$. \\
$\mathrm{resin}$ & $25 \pm 1$ & $20 \pm 1$ & $n . r$. \\
$\mathrm{asph}$ & $85 \pm 3$ & $106 \pm 8$ & $n . r$. \\
$\mathrm{mb}$ & 116 & 115 & \\
$\mathrm{Co}(\mathrm{a}+\mathrm{p})$ & $<0.01$ & $<0.002$ & $n . r$. \\
$\mathrm{resin}$ & $0.12 \pm 0.05$ & 0.075 & $n . r$. \\
$\mathrm{asph}$ & $1.46 \pm 0.05$ & $0.70 \pm 0.04$ & $n . r$. \\
$\mathrm{mb}$ & 109 & 60 & \\
\hline
\end{tabular}

n.r. not reported 
Table 3. Trace element concentrations $\left(\mathrm{mg} \mathrm{kg}^{-1}\right)$ in crude oils, aromatics and polars $(\mathrm{a}+\mathrm{p})$, resin and asphaltenes (asph) fractions with their respective mass balance $(\mathrm{mb}, \%)$. Determination of elements by USN-ICP-MS of toluene solutions

\begin{tabular}{|c|c|c|c|c|c|c|c|c|c|}
\hline$\underline{\text { Sample }}$ & & Mass (g) & $\mathrm{V}$ & Co & $\mathrm{Ni}$ & $\mathrm{Cu}$ & $\mathrm{Zn}$ & Mo & $\mathrm{Pb}$ \\
\hline \multirow{5}{*}{ A } & oil & 1 & 8.9 & 0.41 & 19.3 & 0.54 & 3.1 & 0.045 & 0.36 \\
\hline & $a+p$ & 0.28 & 2.15 & $<0.01$ & 12.4 & $<0.02$ & $<0.07$ & $<0.008$ & $<0.04$ \\
\hline & resin & 0.21 & 19.8 & 0.80 & 42 & 1.06 & 3.4 & 0.070 & 0.51 \\
\hline & asph & 0.053 & 63 & 3.9 & 150 & 6.1 & 52 & 0.67 & 3.6 \\
\hline & $m b$ & & 91 & 91 & 105 & 101 & 112 & 112 & 83 \\
\hline \multirow{5}{*}{ B } & oil & 1 & 8.9 & 0.63 & 17.9 & 0.168 & 3.0 & 0.080 & 0.087 \\
\hline & $a+p$ & 0.27 & 3.9 & $<0.01$ & 10.4 & $<0.02$ & 0.95 & 0.019 & $<0.04$ \\
\hline & resin & 0.21 & 19.5 & 1.00 & 38 & 0.66 & 5.5 & 0.130 & 0.167 \\
\hline & asph & 0.057 & 69 & 6.2 & 163 & 0.61 & 8.5 & 0.96 & 0.87 \\
\hline & $m b$ & & 102 & 89 & 112 & 103 & 63 & 109 & 97 \\
\hline \multirow{5}{*}{$\mathrm{C1}$} & oil & 1 & 5.3 & 0.39 & 10.5 & 0.83 & 3.6 & 0.020 & 0.170 \\
\hline & $a+p$ & 0.34 & 2.5 & 0.36 & 5.3 & 0.075 & 0.31 & $<0.008$ & $<0.04$ \\
\hline & resin & 0.16 & 10.1 & 0.64 & 19.5 & 0.96 & 3.8 & 0.050 & 0.42 \\
\hline & asph & 0.018 & 70 & 6.8 & 157 & 5.8 & 99 & 0.60 & 4.2 \\
\hline & $m b$ & & 70 & 89 & 74 & 34 & 69 & 94 & 84 \\
\hline \multirow{5}{*}{$\mathrm{C} 2$} & oil & 1 & 5.5 & 0.62 & 12.8 & 3.7 & 12.3 & 0.043 & 1.53 \\
\hline & $a+p$ & 0.25 & 2.0 & $<0.01$ & 4.6 & $<0.02$ & $<0.07$ & $<0.008$ & $<0.04$ \\
\hline & resin & 0.23 & 9.0 & 1.15 & 17 & 12.5 & 12.2 & 0.046 & 0.70 \\
\hline & asph & 0.039 & 48 & 6.1 & 135 & 28 & 164 & 0.56 & 25 \\
\hline & $m b$ & & 81 & 81 & 80 & 107 & 75 & 75 & 74 \\
\hline \multirow{5}{*}{ C3 } & oil & 1 & 3.7 & 0.13 & 5.4 & 0.165 & 1.07 & 0.019 & 0.128 \\
\hline & $a+p$ & 0.31 & 1.96 & $<0.01$ & 2.7 & $<0.02$ & 0.61 & $<0.008$ & $<0.04$ \\
\hline & resin & 0.15 & 8.8 & 0.35 & 15.4 & 0.81 & 5.7 & 0.065 & 0.26 \\
\hline & asph & 0.023 & 66 & 3.1 & 122 & 2.2 & 18.5 & 0.30 & 3.9 \\
\hline & $m b$ & & 93 & 95 & 110 & 104 & 137 & 88 & 101 \\
\hline \multirow{5}{*}{ D } & oil & 1 & 10.3 & 0.74 & 18.1 & 0.44 & 3.1 & 0.068 & 0.72 \\
\hline & $a+p$ & 0.28 & 3.7 & $<0.01$ & 7.1 & 0.187 & 0.82 & $<0.008$ & $<0.04$ \\
\hline & resin & 0.26 & 14.2 & 0.66 & 22 & 0.68 & 3.0 & 0.078 & 0.54 \\
\hline & asph & 0.078 & 72 & 5.2 & 158 & 3.0 & 25 & 0.57 & 8.5 \\
\hline & $m b$ & & 100 & 78 & 111 & 105 & 95 & 95 & 112 \\
\hline \multirow{5}{*}{ E1 } & oil & 1 & 7.8 & 0.30 & 11.9 & 0.175 & 4.0 & 0.060 & 0.120 \\
\hline & $a+p$ & 0.34 & 3.2 & $<0.01$ & 7.6 & $<0.02$ & 0.71 & $<0.008$ & $<0.04$ \\
\hline & resin & 0.20 & 11.6 & 0.44 & 15.9 & 0.51 & 4.5 & 0.142 & 0.23 \\
\hline & asph & 0.033 & 80 & 3.7 & 170 & 1.46 & 40 & 0.71 & 1.57 \\
\hline & $m b$ & & 78 & 70 & 96 & 86 & 62 & 86 & 82 \\
\hline \multirow{5}{*}{ E2 } & oil & 1 & 9.2 & 0.42 & 13.0 & 0.20 & 1.38 & 0.060 & $<0.04$ \\
\hline & $a+p$ & 0.34 & 2.1 & $<0.01$ & 7.4 & $<0.02$ & 0.85 & $<0.008$ & $<0.04$ \\
\hline & resin & 0.24 & 20 & 0.60 & 20 & 0.40 & 1.21 & 0.089 & 0.138 \\
\hline & asph & 0.041 & 79 & 5.2 & 141 & 0.97 & 14.5 & 0.75 & 0.44 \\
\hline & $m b$ & & 95 & 85 & 101 & 68 & 85 & 87 & \\
\hline \multirow{5}{*}{ E3 } & oil & 1 & 9.7 & 0.46 & 17.8 & 1.33 & 2.3 & 0.053 & 1.42 \\
\hline & $a+p$ & 0.33 & 1.39 & $<0.01$ & 6.2 & $<0.02$ & $<0.07$ & $<0.008$ & $<0.04$ \\
\hline & resin & 0.25 & 21 & 0.69 & 34 & 2.1 & 3.8 & 0.085 & 0.93 \\
\hline & asph & 0.050 & 83 & 5.5 & 150 & 9.8 & 23 & 0.71 & 25 \\
\hline & $m b$ & & 102 & 97 & 101 & 76 & 91 & 107 & 104 \\
\hline \multirow{5}{*}{$\mathbf{F}$} & oil & 1 & 13.8 & 0.90 & 25 & 0.23 & 0.76 & 0.090 & 0.23 \\
\hline & $a+p$ & 0.33 & 1.76 & $<0.01$ & 7.4 & $<0.02$ & $<0.07$ & $<0.008$ & $<0.04$ \\
\hline & resin & 0.24 & 21 & 0.68 & 31 & 0.79 & 1.39 & 0.080 & 0.67 \\
\hline & asph & 0.056 & 83 & 11.4 & 189 & 0.83 & 7.4 & 1.34 & 1.70 \\
\hline & $m b$ & & 74 & 89 & 82 & 103 & 98 & 105 & 111 \\
\hline
\end{tabular}




\section{Biomarkers and other geochemical data}

Geochemical analyses were performed in the laboratories at the PETROBRAS Research and Development Center (CENPES), Rio de Janeiro, Brazil. The whole oil samples were analyzed by gas chromatography (Hewlett Packard $5890 \mathrm{~A}^{\circledR}$ ) equipped with a split-less injector and a 30-m DB-5 column. The carrier gas was hydrogen, and column temperature was programmed from 40 to $80^{\circ} \mathrm{C}$ at a gradient of $8^{\circ} \mathrm{C} \mathrm{min}-1$ and from 80 to $320^{\circ} \mathrm{C}$ at $4^{\circ} \mathrm{C} \mathrm{min}{ }^{-1}$. One aliquot was fractionated through liquid chromatography in saturated and aromatic hydrocarbons and NSO compounds with aliquots of $n$-hexane, $n$-hexane + dichloromethane (3:2), and methanol, respectively, using silica gel (63-200 mesh) as stationary phase and online UV detection. The biomarkers were determined in the saturated compounds fraction by gas chromatography-mass spectrometry (Hewlett Packard HP-5890® MS coupled to a Hewlett Packard HP-5890A ${ }^{\circledR}$ GC) equipped with an on-column injector and fitted with a $25 \mathrm{~m}$ SE-54 column. Helium was used as the carrier gas, and the column temperature was programmed from 70 to $190^{\circ} \mathrm{C}$ at $30^{\circ} \mathrm{C} \mathrm{min}^{-1}$ and from 190 to $290^{\circ} \mathrm{C}$ at $2^{\circ} \mathrm{C} \mathrm{min}^{-1}$.

About $1 \mathrm{mg}$ of oil was placed in a 9-mm o.d. quartz tube with approximately $1 \mathrm{~g}$ of $\mathrm{CuO}$. Then the tube was evacuated, sealed by fusion and combusted at $850^{\circ} \mathrm{C}$ for $2 \mathrm{~h}$. The resulting $\mathrm{CO}_{2}$ was transferred to $6 \mathrm{~mm}$ breakseal tubes by cryogenic distillation, and subsequently analyzed using a mass spectrometer (Finnigan Mat-252 ${ }^{\circledR}$ ). The isotopic composition of carbon is reported in $\delta^{13} \mathrm{C}$, as \%o-deviation from PDB. ${ }^{21}$ Using replicates of NBS 22 oil $\left(\delta^{13} \mathrm{C}=-29.81 \% \text { o } \pm 0.06 \% \text { o }\right)^{22}$ the standard deviation of the results were typically $0.02 \%$ ( $n=29$ replicates $)$.

API gravity was determined using a digital densitometer for liquids according to ASTM 4052 (ISO 12185). The overall methodology was described in earlier works. ${ }^{13-16}$ Sulfur and nitrogen were quantified by a chemiluminescence method described elsewhere. ${ }^{23}$

\section{Results and Discussion}

\section{Association of elements with crude oil fractions}

Elements were considered associated to crude oil fractions when concentration factors were observed and also acceptable mass balances (70\% to $120 \%)$. Analysis of the fractions by ICP-MS, after dissolution in toluene, was the preferred method for elements for which organic standards were available, because it resulted in better mass balances and allowed a higher number of replicates. Vanadium, $\mathrm{Co}, \mathrm{Ni}, \mathrm{Cu}, \mathrm{Zn}, \mathrm{Mo}$ and $\mathrm{Pb}$ were determined by this method in all crude oil samples as well as their fractions, with overall acceptable mass balances (except $\mathrm{Zn}$, Table 3). Other elements were determined in toluene or in the decomposition solutions (Table 4).

As a general trend, trace elements concentrate in the resin fraction with a factor of about two, and in the asphaltenes with factors higher than seven. This concentration factor allowed the determination of trace elements like $\mathrm{Y}$ and the light rare-earth elements ( $\mathrm{La}$, $\mathrm{Ce}, \mathrm{Pr}, \mathrm{Nd}, \mathrm{Sm}$ ) in asphaltenes, not possible by direct determination in the original oil (Table 4). The asphaltene fraction can represent $50 \%$ or more of the elemental content of the crude oil ${ }^{11}$ and is therefore a critical parameter that should be investigated in inorganic geochemical studies. Concentrations of elements in oils and in asphaltenes were plotted for three samples (Figure 2). In general, the elemental patterns of the asphaltenes match perfectly that of the corresponding crude oil, suggesting that this fraction, which can be easily separated from the bulk oil, is an appropriate fingerprint of the original oil. Similar conclusion can be drawn for the resin fraction (not shown here), which could be used whenever the asphaltenes mass is too low. From 4\% (sample F) to $22 \%$ (sample E-1) of $\mathrm{V}$ and $\mathrm{Ni}$ were meaured in the aromatic and polar fraction (Table 3). These elements can be bound to porphyrin structures, like the deoxophylloerythroetioporphyrin (DPEP) and etioporphyrins, which have been identified in similar chromatographic fractions. ${ }^{3}$

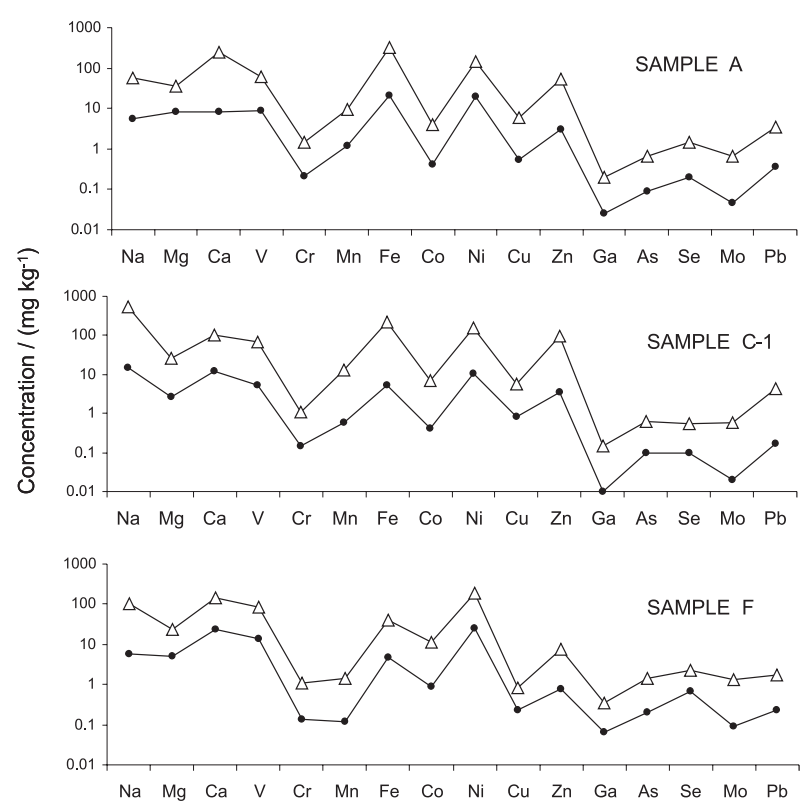

Figura 2. Mean concentrations $\left(\mathrm{mg} \mathrm{kg}^{-1}, n=2\right)$ of 16 elements in three crude oils (A, C-1, F) and their corresponding asphaltenes (triangles). 
Table 4. Trace elements $\left(\mathrm{mg} \mathrm{kg}^{-1}\right)$ in the crude oils and asphaltene fraction, asphaltenes content (asph, $\left.\mathrm{mg} \mathrm{g}^{-1}\right)$; $\mathrm{Y}$ and Light REE in asphaltenes (ng $\mathrm{g}^{-1}$ asph). Determination by USN-ICP-MS of aqueous solutions after acid decomposition assisted by microwaves or (*) toluene solutions. RSD: <10\% for results $>50 \mathrm{ng} \mathrm{g}^{-1} ; 10 \%-30 \%$ for results between $20-50 \mathrm{ng} \mathrm{g}^{-1}$ and $>30 \%$ for results $<20 \mathrm{ng} \mathrm{g}^{-1}$

\begin{tabular}{|c|c|c|c|c|c|c|c|c|c|c|}
\hline & A & $\mathrm{B}$ & $\mathrm{C}-1$ & $\mathrm{C}-2$ & $\mathrm{C}-3$ & $\mathrm{D}$ & E-1 & E-2 & E-3 & $\mathrm{F}$ \\
\hline $\mathrm{Na}^{*}$ (oil) & 5.47 & 2.60 & 15.40 & 19.00 & 10.70 & 30.00 & 2.10 & 6.50 & 9.00 & 5.70 \\
\hline $\mathrm{Na}^{*}($ asph $)$ & 55.4 & 41.6 & 520 & 300 & 340 & 200 & 56.7 & 122 & 160 & 99.5 \\
\hline $\operatorname{Mg}($ oil) & 8.09 & 2.98 & 2.70 & 2.20 & 1.20 & 6.60 & 5.00 & 2.55 & 5.00 & 5.00 \\
\hline $\mathrm{Mg}($ asph $)$ & 35.7 & 2.62 & 25.2 & 23.6 & 10.4 & 42 & 15 & 9.9 & 20.4 & 24 \\
\hline $\mathrm{Ca}($ oil) & 8.04 & 13.4 & 11.90 & 37.60 & 11.50 & 23.90 & 19.00 & 22.34 & 5.40 & 23.00 \\
\hline $\mathrm{Ca}($ asph $)$ & 250 & 9.33 & 102 & 417 & 60.5 & 206 & 247 & 77.6 & 200 & 143 \\
\hline Cr(oil) & 0.22 & 0.15 & 0.15 & 2.07 & 0.09 & 11.80 & 0.29 & 0.11 & 1.24 & 0.14 \\
\hline $\mathrm{Cr}$ (asph) & 1.5 & 0.43 & 1.07 & 13.8 & 0.56 & 63.6 & 0.67 & 0.68 & 0.94 & 1.07 \\
\hline Mn*(oil) & 1.20 & 0.20 & 0.57 & 0.30 & 0.00 & 0.22 & 0.37 & 0.09 & 0.17 & 0.12 \\
\hline $\mathrm{Mn} *(\mathrm{asph})$ & 9.2 & 0.43 & 13.3 & 3.79 & 0.79 & 1.97 & 3.02 & 1.13 & 2.57 & 1.45 \\
\hline $\mathrm{Fe}^{*}$ (oil) & 20.50 & 0.75 & 5.44 & 2.75 & 0.36 & 3.60 & 2.27 & 3.12 & 10.90 & 4.68 \\
\hline $\mathrm{Fe}^{*}(\mathrm{asph})$ & 327 & 7.5 & 221 & 27.8 & 11.9 & 36.6 & 27.2 & 28.3 & 132 & 40 \\
\hline $\mathrm{Ga}$ (oil) & 0.025 & 0.060 & 0.010 & 0.010 & $<0.001$ & 0.040 & 0.020 & 0.020 & 0.020 & 0.065 \\
\hline $\mathrm{Ga}(\mathrm{asph})$ & 0.2 & 0.32 & 0.15 & 0.1 & 0.2 & 0.19 & 0.16 & 0.13 & 0.15 & 0.34 \\
\hline As(oil) & 0.09 & 0.18 & 0.10 & 0.11 & 0.00 & 0.07 & 0.20 & 0.06 & 0.13 & 0.20 \\
\hline As(asph) & 0.67 & 0.2 & 0.63 & 0.5 & 0.07 & 0.38 & 0.35 & 0.19 & 0.52 & 1.44 \\
\hline $\operatorname{Se}($ oil $)$ & 0.20 & $<0.01$ & 0.10 & $<0.01$ & $<0.01$ & $<0.01$ & 0.71 & 0.85 & 0.49 & 0.68 \\
\hline $\mathrm{Se}$ (asph) & 1.43 & $<0.02$ & 0.55 & $<0.02$ & 0.3 & $<0.02$ & 1.03 & 0.94 & 1.47 & 2.2 \\
\hline Mass asph & 53 & 57 & 18 & 39 & 23 & 78 & 33 & 41 & 50 & 56 \\
\hline $\mathrm{Y}(\mathrm{asph})$ & 74 & 54 & 12 & 21 & 7 & 125 & 60 & 38 & 82 & 110 \\
\hline $\mathrm{La}(\mathrm{asph})$ & 125 & 70 & 7 & 30 & 12 & 125 & 27 & 28 & 56 & 82 \\
\hline $\mathrm{Ce}(\mathrm{asph})$ & 250 & 101 & 50 & 81 & 56 & 410 & 76 & 68 & 135 & 60 \\
\hline $\operatorname{Pr}($ asph) & 26 & 8 & 2 & 7 & $<0.001$ & 25 & 8 & 6 & 13 & 6 \\
\hline $\mathrm{Nd}$ (asph) & 93 & 28 & 8 & 30 & $<0.003$ & 94 & 30 & 18 & 59 & 28 \\
\hline $\mathrm{Sm}$ (asph) & 15 & 4 & 1 & 7 & 1 & 22 & 8 & 4 & 13 & 10 \\
\hline
\end{tabular}

\section{Biodegradation assessment through geochemical indicators and elements}

The petroleum geochemistry of this area has been discussed elsewhere in detail ${ }^{13-16}$ and indicates an oil origin from a single marine-evaporitic source rock, deposited under restricted conditions ${ }^{24}$ showing bacterial homohopane $\mathrm{H}_{35} / \mathrm{H}_{34}$ near unity and a gammacerane index higher than 60 (Table 5). In this specific case of a single origin, variations of the above-cited indicators are related to other influences, like biodegradation. Steranes isomerization $\left(C_{29} \beta \beta /(\alpha \alpha+\beta \beta), S /[S+R]\right)$ display a small interval of 0.3-0.4 (Table 5), with only sample C-3 (0.45) being near the maturity value $(0.5)$.

Biodegradation is a predominant effect on the trend, and a qualitative assessment is purposed on the basis of bulk parameters (Table 5, Figure 1b). At least two general groups are distinguished: 1) slightly to moderately degraded oils (A to D) with alteration in the alkene's distribution up to $60 \mathrm{~km}$, and 2) heavily degraded oils (E-1 to F) with little or no $\mathrm{C}_{3}-\mathrm{C}_{25} n$-alkanes and isoprenoids (pristane, phytane) after $80 \mathrm{~km}$. Nitrogen, S, Ni and V concentrations are inversely proportional to API gravity (Figure 3). Correlations of N, S, Ni and V with API gravity indicate variations in the degree of biodegradation, when steranes are still not degraded. ${ }^{25}$ In the present case, samples show $\mathrm{S}$ and $\mathrm{N}$ concentrations below $1 \%$, observed in oils with non-altered steranes. The overall variation show an increase in the extent of biodegradation with distance of migration, except samples A and B in locally degraded reservoirs. Quantification of biodegradation is more easily established by the quantification of compounds like the bacterial homohopanes or elements like $\mathrm{V}$ and $\mathrm{Ni}$, which are concentrated under hydrocarbon loss. ${ }^{26}$ Cobalt and Mo in the bulk oil follow V and Ni distribution (Table 3, Figure 4a), suggesting that these elements could also be used for the assessment of biodegradation.

$\mathrm{Ni} / \mathrm{V}$ ratio is influenced by geochemical effects such as source and maturity, due to bounded porphyrin nuclei. ${ }^{27}$ The variations of $\mathrm{Ni} / \mathrm{V}$ ratio with distance from the source were established for the ten crude oils and their three fractions of interest: asphaltenes, aromatics-polars and resins. The ratio 
Table 5. Characteristic geochemical parameters of the crude oils and their distance from source: API gravity; concentrations $(\%)$ of $\mathrm{S}$ and $\mathrm{N} ; \delta^{13} \mathrm{C} ; n$-alkanes occurrence; ratio of $\mathrm{C}_{20}$ isomers pristane and phytane (Pri/Phy); ratio of enantiomeres on $\mathrm{C}_{20}: \mathrm{S} /(\mathrm{S}+\mathrm{R})$ of the $5 \alpha(\mathrm{H}) 14 \alpha(\mathrm{H}) 17 \alpha(\mathrm{H})$-ethylcholestanes and ratio of $14 \beta(\mathrm{H}) 17 \beta(\mathrm{H}) /(14 \beta(\mathrm{H}) 17 \beta(\mathrm{H})+14 \alpha(\mathrm{H}) 17 \alpha(\mathrm{H}))$ - ethylcholestanes $\left(\mathrm{C}_{29} \beta \beta / \mathrm{C}_{29}\right)$; gammacerane index $=$ gammacerane area $\times 100 / 17 \alpha(\mathrm{H})$, $21 \beta(\mathrm{H})$ - hopane (gam. ind.); ratio of $\left(22 \mathrm{~S}+22 \mathrm{R} \mathrm{C} \mathrm{C}_{35} 17 \alpha(\mathrm{H}), 21 \beta(\mathrm{H})\right.$-hopanes) / $\mathrm{C}_{34}$ counterpart $\left(\mathrm{H}_{35} / \mathrm{H}_{34}\right)$

\begin{tabular}{lcccccccccc}
\hline & $\mathrm{A}$ & $\mathrm{B}$ & $\mathrm{C}-1$ & $\mathrm{C}-2$ & $\mathrm{C}-3$ & $\mathrm{D}$ & $\mathrm{E}-1$ & $\mathrm{E}-2$ & $\mathrm{E}-3$ & $\mathrm{~F}$ \\
\hline distance $(\mathrm{km})$ & 46 & 51 & 54 & 55 & 57 & 82 & 86 & 91 & 95 & 104 \\
API gravity & 23.1 & 19.6 & 26 & 24.9 & 23.4 & 18.5 & 16.1 & 16.6 & 15.7 & 11.4 \\
$\% \mathrm{~S}$ & $\mathrm{n} . \mathrm{a}$ & 0.72 & 0.46 & 0.52 & 0.43 & 0.81 & 0.66 & 0.69 & 0.73 & $n . a$. \\
$\% \mathrm{~N}$ & 0.34 & 0.37 & 0.26 & 0.26 & 0.26 & 0.43 & 0.42 & 0.41 & 0.44 & $n . a$. \\
$\left(\delta^{13} \mathrm{C}\right)$ & -26.3 & -26.1 & -26.2 & -26.1 & -26.0 & -26.2 & -25.7 & -26.0 & -25.6 & -25.7 \\
$n$-alkanes & $n \mathrm{C}_{5}-n \mathrm{C}_{38}$ & $n \mathrm{C}_{12}-n \mathrm{C}_{38}$ & $n \mathrm{C}_{13}-n \mathrm{C}_{38}$ & $n \mathrm{C}_{12}-n \mathrm{C}_{38}$ & $n \mathrm{C}_{5}-n \mathrm{C}_{38}$ & $n \mathrm{C}_{12}-n \mathrm{C}_{38}$ & $n . d$. & $n . d$. & $n . d$. & $n . d$. \\
Pri/Phy & 0.95 & 0.93 & 0.87 & 0.81 & 0.77 & 0.78 & $n . d$. & $n . d$. & $n . d$. & $n . d$. \\
$\mathrm{S} /(\mathrm{S}+\mathrm{R})$ & 0.36 & 0.35 & 0.38 & 0.34 & 0.45 & 0.37 & 0.40 & 0.40 & 0.38 & 0.32 \\
$\mathrm{C}_{29} \beta / \mathrm{C}_{29}$ & 0.33 & 0.35 & 0.38 & 0.34 & 0.47 & 0.34 & 0.40 & 0.38 & 0.38 & 0.30 \\
$\mathrm{Gam}_{\text {ind. }}$ & 72 & 72 & 61 & 63 & 66 & 74 & 74 & 80 & 79 & 77 \\
$\mathrm{H}_{35} / \mathrm{H}_{34}$ & 0.91 & 0.83 & 0.81 & 0.76 & 0.84 & 0.85 & 0.86 & 0.88 & 0.86 & 0.94 \\
\hline
\end{tabular}

n.a. not analysed; n.d. not detected
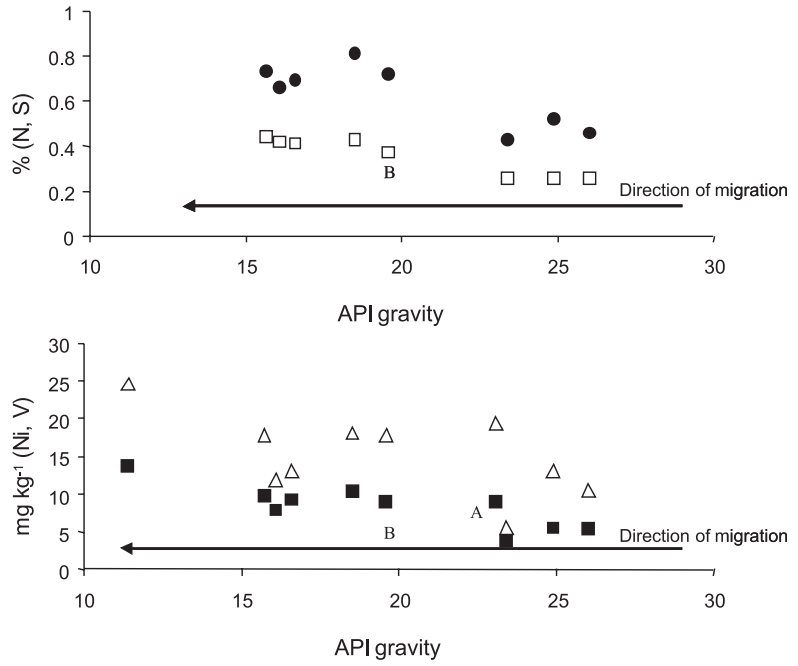

Figura 3. Variations in the concentrations of $\mathrm{S}(\bullet), \mathrm{N}(\square), \mathrm{Ni}(\square)$ and $\mathrm{V}(\Delta)$ with API gravity in the crude oils.

shows no specific trend in the oils, asphaltenes and resins, displaying respective values of $1.8 \pm 0.3,1.7 \pm 0.3$ and 2.2 \pm 0.3 . In contrast, two trends were observed in the aromatic and polar fraction, occurring reversion of the slopes at about $70 \mathrm{~km}$ (Figure 5). A similar profile is observed for the $\mathrm{H}_{35} / \mathrm{H}_{34}$ ratio with distance, and also with the gammacerane index (Table 4), which suggests that biodegradation is influencing the $\mathrm{Ni} / \mathrm{V}$ ratio in this fraction. The first decrease in biodegradation is difficult to interpret and might be the result of reservoir heterogeneities or local degradation. The increase of biodegradation after $80 \mathrm{~km}$ is due to the residual character of the oils in shallower reservoirs. Breakouts have been identified as consequences of local stress around the middle of the trend (fields were sample D was collected), which can explain the 60 to $80 \mathrm{~km}$ boundary. ${ }^{28}$
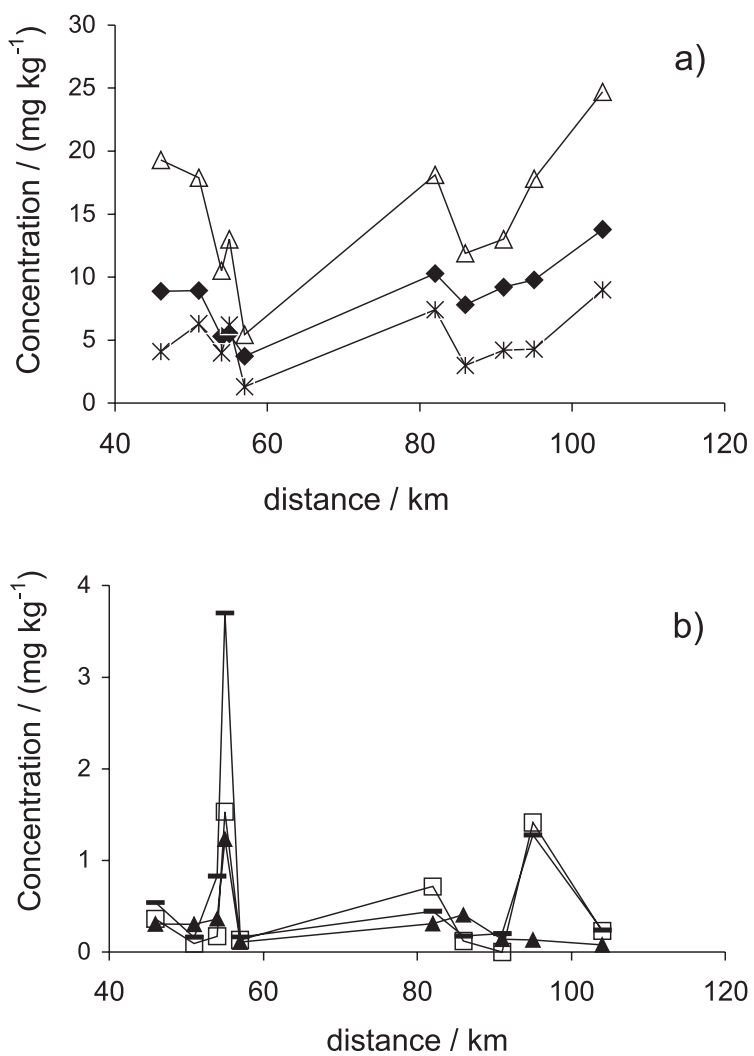

Figura 4. Variations in the concentrations (in $\mathrm{mg} \mathrm{kg}^{-1}$ ) of elements in crude oils with distance from the source rocks: a) V $(\bullet), \mathrm{Ni}(\triangle)$, Co x $10(*)$ and b) $\mathrm{Cu}(-), \mathrm{Zn}: 10(\mathbf{\Delta})$ and $\mathrm{Pb}(\square)$. For $\mathrm{Co}$ and $\mathrm{Zn}$, a scaling factor was used for better data display.

\section{Association of elements to water and minerals}

Copper, $\mathrm{Zn}$ and $\mathrm{Pb}$ showed different distributions than $\mathrm{V}$ and $\mathrm{Ni}$ (Figure $4 \mathrm{~b}$ ). High concentrations were observed in oils and asphaltenes for two samples C-2 and E-3. The 

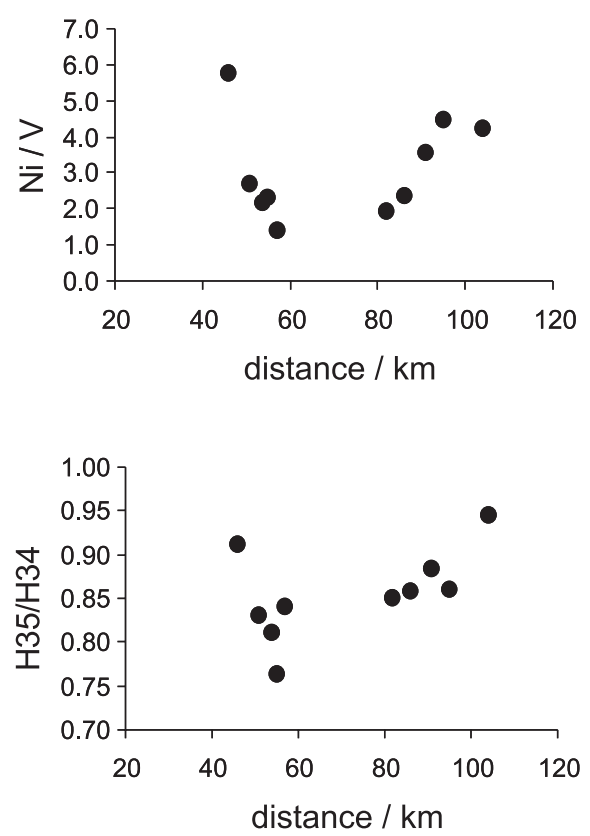

Figura 5. Ni/V variations in the aromatic and polar fraction and $\mathrm{H} 35 / \mathrm{H} 34$ homohopane ratio with distance from the source rocks.

carrier bed, constituted by sediments of the Açu Formation, has a high permeability ${ }^{29}$ that would permit infiltration of meteoric waters. These elements were possibly carried to the oil/water contact and incorporated in the bulk oil as soluble and insoluble salts. Washing of the crude oils with ultra-pure water resulted in significant concentrations of $\mathrm{Cu}, \mathrm{Zn}$ and $\mathrm{Pb}$ (10-100 $\left.\mathrm{ng} \mathrm{g}^{-1}\right)$ in the aqueous extract and a corresponding decrease in the oil sample. For example, $\mathrm{Pb}$ concentrations in the washed C-2 and E-3 samples were 40 and $60 \%$ lower than in the original sample. These observations suggest that these elements are partly associated with emulsified water as soluble salts, and may be concentrated in asphaltenes during the separation procedure. This can be observed also for all other elements determined, except V, Co, Ni, Mo and $\mathrm{Ga}$, whose concentrations were not significantly reduced by washing. More detailed research has been performed in our laboratory for the chemical characterization of oil water and its role in elemental partitioning and reservoir geochemistry. ${ }^{30}$

Concentrations of $\mathrm{Y}$ and the LREE (La-Sm) in asphaltenes varied together with the asphaltenes content along the migration trend (Table 4), suggesting that they are related to asphaltenes formation. Asphaltenes can form during petroleum migration as a result of hydrocarbon loss, lowering of temperature and increase of viscosity. ${ }^{31}$ Part of these elements could have been incorporated after oil formation and expulsion through the migration bed. The bed, which is part of the Açu Formation, is essentially composed of quartz, feldspar and carbonates, with marine-evaporitic influences. ${ }^{16}$ In sedimentary rocks, REE are mostly present in the clay fraction. A study on K-feldspar formation within the Açu sandstones showed that these minerals of a predominant kaolinitic type were infiltrated mechanically during dissolution-precipitation episodes $^{32}$ and could be incorporated during aggregation of asphaltenes in heavier, biodegraded or residual oils. Clays and their associated REE have already been identified in other crude oils. ${ }^{33}$ In a recent study, ${ }^{30}$ REE showing a characteristic positive anomaly of europium, have also been identified in formation water associated with crude oil.

\section{Conclusions}

Fractionation of crude oil into asphaltenes and resins was successfully used as a pre-concentration procedure for trace and ultra-trace element determination by ICP-MS. Most interestingly, elemental distribution patterns in asphaltenes matched that of the corresponding crude oils, opening new perspectives for the fingerprinting of oil using these more refractory compounds, in addition to the more common organic biomarkers. Geochemical effects were observed on the elemental distribution of crude oils and fractions in a case study, where secondary migration occurred along a linear trend. The single marine-evaporitic source and small variation of maturity permitted to trace biodegradation effects on the oils. Discrimination between elements and comparison of variations of concentrations in the oil and its separated fractions of light polars, resins and asphaltenes, revealed probable different sources, as well as different mechanisms of incorporation into the oil bulk. Vanadium, $\mathrm{Co}, \mathrm{Ni}$ and Mo were influenced by biodegrading processes and accumulate in the most biodegraded and migrated samples. The variation of $\mathrm{Ni} / \mathrm{V}$ in the aromatic and polar fraction matched the one of homohopane and gammacerane ratios in paraffin, indicating that biodegradation is traceable by this ratio in a fraction that presumably contains labile porphyrins. Copper, $\mathrm{Zn}$ and $\mathrm{Pb}$ had similar distribution pattern in oil as well as in its heavier fraction of asphaltenes, but distinct from the $\mathrm{V}, \mathrm{Co}, \mathrm{Ni}$ and Mo ones. Part of these elements was associated to the water phase emulsified in the oil bulk. They were possibly incorporated as salts from meteoric water percolation in the porous sandstone through the oil-water contact. Strong enrichment of trace elements in the separated asphaltene fractions permitted their determination with higher confidence level, specifically for $Y$ and the LREE. Their concentrations increased with asphaltene content of the crude oil, indicating a relation with asphaltene formation during secondary migration, possibly associated to mechanical inclusion of clays during asphaltenes aggregation. 


\section{Acknowledgments}

The authors like to thank the PETROBRAS R\&D Center for sample selection and organic data analysis, and Álvaro J. Pereira from PUC-Rio for his skill and dedication in ICP-MS measurements. One of the authors (N.M.) thanks for a research grant received from CNPq. This work was financially supported by CENPES (Petrobras) and FINEP, Brazil.

\section{References}

1. Treibs, A.; Anal. Chemie 1934, 510, 42.

2. Tissot, B. P.; Welte, D. H.; Petroleum Formation and Occurrence. Springer-Verlag: London, UK, 1984.

3. Ocampo, R.; Riva, A.; Trendel J. M.; Riolo, J.; Callot, H. J; Albrecht, P.; Energ. Fuel. 1993, 7, 191.

4. Al-Shahristani, H.; Al-Atyia, M. J.; Geochim. Cosmochim. Acta 1972, 36, 929.

5. Filby, R.; In Geofluids: Origin, Migration and Evolution of Fluids in Sedimentary Basins. Parnell, J., ed.; Geol. Soc. Spec. Pub.: Belfast, 1994, 78, p. 203.

6. Alberdi-Grenolet, M.; Tocco, R.; Chem. Geol. 1999, 160, 19.

7. López, L.; Lo Mónaco, S.; Fuel 2004, 83, 365.

8. López, L.; Lo Mónaco, S.; Galarraga, F.; Lira, A.; Cruz, C.; Chem. Geol. 1995, 119, 255.

9. Duyck, C.; Miekeley, N.; Silveira, C.L.P.; Szatmari, P.; Spectrochim. Acta B 2002, 57, 1979.

10. Duyck, C.; Miekeley, N.; Campos, R. C.; Silveira, C. L. P.; Aucélio, R. Q.; Grinberg, P.; Brandão, G. P.; Spectrochim. Acta B 2007, 62, 939.

11. Yen, T. F.; The role of trace metals in petroleum. Ann Arbor Science Publishers: Ann Arbor, USA, 1975, p.219.

12. Speight, J. G.; Oil Gas Sci. Technol. 2004, 59, 467.

13. Trindade, L. A. F.; PhD Thesis, Stanford University, USA, 1992.

14. Trindade, L. A. F.; Brassell, S.C.; Org. Geochem. 1992, 19, 13.

15. Santos Neto, E. V.; PhD Thesis, Indiana University, USA, 1996.
16. Santos Neto, E. V., Hayes, J. M.; Takaki, T.; Org. Geochem. 1998, 28, 361.

17. Fonseca, T. C. O.; PhD Thesis, Pontifícia Universidade Católica do Rio de Janeiro, Brazil, 2000.

18. Duyck, C. B.; PhD Thesis, Pontifícia Universidade Católica do Rio de Janeiro, Brazil, 2001.

19. Souto Filho, J. D.; Correa, A. C. F.; Santos Neto, E. V.; Trindade, L. A. F. In AAPG/ABGP Joint Research Symposium: Petroleum Systems of the South Atlantic Margin, November, 16-19, 1997, Rio de Janeiro, Brazil.

20. Perreira, C. E. B.; Miekeley, N.; Poupeau, G.; Küchler, I. L.; Spectrochim. Acta B 2001, 56, 1927.

21. Urey, H. C.; Lowenstam, H. A.; Epstein, S.; McKinney, C. R.; Geol. Soc. Am. Bull. 1951, 16, 399.

22. Schoell, M.; Faber, E.; Coleman, M. L.; Org. Geochem. 1983, 5,3 .

23. Stoddart, D. P.; PhD Thesis, University of Newcastle upon Tyne, UK, 1993.

24. Mello, M. R.; Gaglianone, P. C.; Brassell, S. C.; Maxwell, J.R.; Mar. Petrol. Geol. 1988, 5, 205.

25. Wenger, L. M.; Davis, C. L.; Isaksen, G. H.; SPE Reserv. Eval. Eng. 2002, 5, 375.

26. Peters, K. E.; Walters, C. C.; Moldowan, J. M.; The Biomarker Guide: Biomarkers and Isotopes in Petroleum Systems and Earth History, $2^{\text {nd }}$ ed., Cambridge University Press: New York, 2004, v. 2.

27. Barwise, A. J. G.; Amer. Chem. Soc. Spec. Pub., 1987, 100.

28. Ferreira, J. M.; Oliveira, R. T.; Takeya, M. K.; Assumpção, M.; Geophys. J. Int. 1998, 134, 341.

29. Lima Neto F. F.; I Seminário de Interpretação Exploratória - SINTEX, Petrobras, Rio de Janeiro, Brazil, 1989.

30. Teixeira, H. M. F.; PhD Thesis, Pontifícia Universidade Católica do Rio de Janeiro, Brazil, 2007.

31. Wilhelms, A.; Larter S.R.; Mar. Petrol. Geol. 1994, 11, 418.

32. Maraschin, A. J.; Mizusaki, A. M.; De Ros, L. F.; J. Geol. 2004, 112, 317 .

33. Jacobs, F. S. U.; PhD Thesis, Washington University, USA, 1982.

Received: November 17, 2007 Web Release Date: May 29, 2008 